\title{
Church and agapocracy: The rule of love
}

\section{ABSTRACT}

At the heart of Christian faith and the life of the Church lies the conviction that God is love and that this is the rule by which the Christian community and indeed all of humanity is to be guided and judged. However, responding to the Scriptural witness of love as agapè - as practical faithfulness and self-giving to "the other" - is challenging and quite often very problematic. What is involved in "loving the Lord your God"? What is asked of us in the command to "love one's enemy as oneself"? How is the church called to manifest agape in society? This contemplative essay reflects on these questions, revealing what is at stake in current debates in ecclesiology, ethics and the Christian life where love is claimed to rule.

\section{GOD IS LOVE}

"God is love." This phrase from the letter of John is one of the best known texts of the Bible. This is the core of what Christians confess of God: love. And it is within this paradigm that we must develop Christian theology and Christian ethics. Christianity and love belong intrinsically together, so much so that it does not even seem interesting at all to write about it once again.

In this article I will argue that love is problematic. This is crucial, not so much because people speak more easily about love than live it. That too, is well known. It is more about the concept of love as such, and about the fundamental dilemmas we face if we want to implement it. The problematic nature of love is not due to our weakness and lack of love, but rather to the inner conflicts which the concept of love evokes for Christian faith and Christian life. Christian love is not something romantic. Rather, it is hard labour, a struggle on unpaved roads through thorny bush, where we cannot find our way.

\section{EROS AND AGAPÈ}

The discussion on Christian love has been strongly influenced by Nygren's famous book Eros och Agapè (Nygren,1930; 1936). The Greek language has two major words for what western languages label as 'love'. The most common word in Greek is eros. In modernity this is almost exclusively related to sexual love, but in classic Greek this is different. It is best rendered with notions like 'desire'. What is your desire? What are you longing for? Where does your interest lie? What is the object of your love? That might be money, honour, sexual lust, food. It might also be the happiness of your children, the wellbeing of your partner, the highest good that calls for ultimate ethics and thus is the object of ultimate love. Love for the ultimate good is love par excellence. Eros is desire and its fulfilment expresses the identity of the person who loves. Tell me what satisfies you, and I will tell you who you are.

The other word is agapè. According to Nygren, agapè is not related to desire but to giving. It is love without any self-interest. Only the interest of the other is in focus, and I sacrifice my own 
NGTT: Oopbron - http://ngtt.journals.ac.za

desires and interests on behalf of the other one. It is this love about which the New Testament speaks. Eros does not occur once in the New Testament, while agapè and related words are used frequently. This is the kind of love that Christian faith is all about.

The influence of Nygren's study has been enormous. Though it has been much contested as well, the framework has been dominant: the opposition of eros and agapè. Those who do not follow Nygren usually argue that we should not make this opposition absolute. Desire for the good is not wrong. It belongs to true love and relationships. Even the desire for the good of the other one is a desire and its satisfaction is the result of true love. Divine love is also desire. Pope Benedictus argues likewise in his encyclical Deus est Caritas (Benedictus XVI, 2005). I think it is right to combine both desire and unselfish giving in love, if we put it into this framework. I can understand Nygren against the background of nineteenth century liberal theology with its focus on self-loving in the development of personhood, but his opposition is too simple and does not take into account that self-sacrifice can also be used to call young boys to the battlefields of Verdun on behalf of the fatherland (cf. Van de Beek, 2006).

\section{The choice of the translators of the Old Testament}

The word agapan is very rare in Greek. Nevertheless, the translators of the Old Testament opted for it. It is generally agreed that there are two reasons why they did so. The first is the similarity in sound with the Hebrew 'ahab, the Hebrew word for love. ' The main reason however will be its meaning. Agapè has no specific meaning in Greek (Stauffer 1964:38; Wallis 1973:110). It is a low level word of practical life. It is not a word that calls on deep emotions like eros or higher feelings as the other Greek word for love, philia, does. "In the word agapan the Greek finds nothing of the power or magic of eran and little of the warmth of philein" (Stauffer, 1964:38).

By choosing this word, the translators of the Old Testament contributed a different approach to Greek thought on love: its focus is not on feelings, either of desire or of intimacy and friendship, but on concrete actions. It is this meaning that made agape the fitting word for love according to the Old Testament. Love is first of all keeping to the rules you have to obey. Other aspects are not excluded, but they are not the core of love. A covenant can be made because the participants like each other (e.g. 1 Sam. 20:16v; 23:18), but the implementation of the covenant is first of all that they keep to its agreements and clauses (2 Sam. 21:7). God's love for Israel is that He keeps to the covenant and He requires the same from his people. Even in the case of love between partners in marriage, it is not only about feelings, but even more on being faithful and trustworthy. 'Der Ausdruck ' $h b$ und dessen Ableitungen weisen im AT eine auffällig pragmatischen Zug auf. Liebe setzt nicht nur reine konkrete innere Disposition voraus, die durch Erfahrungen oder Erlebnisse aufgebaut wird, sondern sie schliesst von sich au sein bewustes Handeln um des geliebten Menschen oder der bevorzugten Sache willen ein. In diesem Sinne ist Liebe schliesslich soziologisch, ja sogar sozial-ethisch bestimmt' (Wallis, 1973:112).

\footnotetext{
1. One could imagine that the word agape is borrowed in Greek from Semitic 'ahab because Phoenician merchants used the word. It thereby became a word in those circles and not of literature and philosophy. This is, however, not plausible, because the root 'ahab is hardly present in Semitic languages other than Hebrew. So it might be considered as a specific semantic field for expressing righteous relations in the sphere of the religion that is embedded in that tradition in Israel which is represented in present canonical literature, and its "etymology is obscure" (Stauffer, 1964:21). It might even be that the word entered the Greek from the Jewish diaspora, because Jews preferred a Hebraism for expressing their opinion about love rather than using a Greek word with a different character. This would fit the late occurrence of agapè in Greek texts (Stauffer, 1964:37f).
} 
God is love and the God of Israel should be loved. The core text about loving God, the shema: "Love the Lord your God with all your heart and with all your soul and with all your strength" (Dt. 6:5) is not about feelings and desires, but about commandments; not as an arbitrary law but as the rule for good living. It has to do with your acting in obedience to God's directions for life. It does not ask: "Do you have deep feelings for me or are you longing for me?", but: "Can I trust you? Are you, as a servant, obedient to the commands and do you keep to the agreement we made?" Agapan is about concrete actions in obedience to the law: "And now, Israel, what does the Lord your God ask of you but to fear the Lord your God, to walk in obedience to him, to love him, to serve the Lord your God with all your heart and with all your soul, and to observe the Lord's commands and decrees that I am giving you today for your own good?"(Dt. $10: 12 f ;$ cf. $11: 1,13,22 ; 30: 16,20)$. This is the way we must deal with other people also, not only with our friends, but also with foreigners: "He loves the foreigner residing among you, giving them food and clothing" (Dt. 10:18).

The New Testament adhered to the language of the canonical books of the Septuagint. It does not use eros once, probably because of the increasingly sexual connotations of lust in the word. Philein occurs sometimes, especially if it is about friendship, for instance of Jesus and Lazarus (Jn 11:3). The normal word is agape.. ${ }^{2}$ Do you keep to what is expected of you? Are you trustworthy? In the New Testament too, love is focused more on actions than on feelings. ${ }^{3}$ Agapè is the core of Christian life and its basis is not that we have good feelings about others, but that we keep to the commandments. Philein is even used in this meaning by Jesus himself: "You are my friends if you do what I command." That is not the way we usually speak about friendship. If my friend should say: "You are my friend if you do what I command"I would not feel this to be the highest expression of friendship. I would rather prefer the classic connotations of philia. But this is the way Christian love is structured. ${ }^{4}$ Philia must be interpreted from the basic meaning of agapè and not agapè from the understanding of classic philia. And if it is about philein, then it is about the verb, about action, and not about the substantive philia. The latter occurs only once in the New Testament - and there in a negative connotation: friendship of the world (Jm 4:4). ${ }^{5}$

2. The root phil- occurs 55 times, while agapa- is 321 times present.

3. You can see this e.g. in the chain: godliness, brotherly kindness (philadelphia), love (agapè) in 2 Peter 1:7. Agapè is the apex of Christian life.

4. The meaning of pistis is similar to this. Though the word is often translated by 'faith' it is better rendered by 'faithfulness'. A characteristic verse is Romans 1:17: "For in the gospel the righteousness of God is revealed - a righteousness that is by faith from first to last, just as it is written: 'The righteous will live by faith." It is a core text in the Lutheran tradition and in Protestantism as a whole: Christians are not saved by works but by faith. We should, however, relate verse 17 to verse 4: "who through the Spirit of holiness was appointed the Son of God in power by his resurrection from the dead: Jesus Christ our Lord." Christ is risen from death because He was faithful, keeping to the commandments of the Father, obedient to death (Php. 2:9) and He is the righteous one who lives by his faithfulness (pistis). This is a congenial reference to Habakkuk 2:4 and not at all against Luther's drive, but rather even more in line with him: it is not our own faith that saves us, but only Jesus' faithfulness. See also Theron, 2010.

5. I will not enter here into the debate about agapan and philein in John 21:15-17. Though it is not tenable that both words cannot be used synonymously, and John often prefers using synonyms I agree with McKay... that the meaning of words must be derived of their use in the context. "Like" and "love" in English can be used as synonyms, but these words keep their own colour and, when used together, we must see whether synonymy is probable or distinctive. In the case of John 21 there might be arguments for distinction, but even then the question is: "Which distinction?" See Ray 2002: 392f. 


\section{Deuteronomy}

Love is problematic. The shema says: "Love the Lord your God"'(Dt. 6:5). That is the love to which Israel is called. It sounds, almost obviously, just like: "and your neighbour as yourself", as Jesus continued (Mt. 22:39) with reference to another verse of the torah (Lv. 19:16). This also includes the foreigners (Lv. 19:34). However, after the shema in Deuteronomy 6, follows Deuteronomy 7. This chapter orders Israel to totally annihilate all the people in the land of Canaan, all men, women and children - even to erase any memory of their culture. It is an order for absolute genocide, without any exception. It commands a total destruction of people and their culture. So doing, Israel will demonstrate its love to God. ${ }^{6}$ You are my friends if you will do my commandments. Tell me who your friends are, and I will tell who you are.

Only in the fulfilment of the Old Testament in Christ can we understand its meaning. Without Christ it is not only an incomprehensible mystery, but also a curse for all people - certainly not a blessing as God promised in Genesis (12:3). The Good Shepherd gives his life for his sheep (Jn 10:11). He died on behalf of them - also for the sheep that did not belong to the stable of Israel (Jn 10:16). It is only in the death of Christ on behalf of humanity that we can understand the shema and its subsequent chapter - and all chapters of the Old Testament. ${ }^{7}$

Therefore, we can only think about love in the remembrance of the death of Christ. Jesus encounters Peter after his denial at a meal (Jn 21:11-14). It is only at the Eucharist that we will understand such love, where the fish (ichthus) is eaten: Jesus, who gives himself as a source of eternal life. Without Christ, biblical love is a dark mystery. At the Eucharist it becomes the mystery of faithfulness unto the very end - as it was Jesus who loved his own until the very end. It is the love of Him who gave Himself when we were enemies (Rm. 5:10). Love is based on the love of God, who, "if we are faithless, remains faithful, for he cannot disown himself" (2 Tim. 2:13).

\section{LOVE FOR THE ENEMIES}

Now we come to another hard aspect of Christian love: you must love your enemies (Mt. 5:44; $6: 27,35$ ). If it is about romantic love or friendship this would be a square circle - an utopian ideal, which is so idealistic that it can only be eschatological in a future sense - and thus not relevant for now. Love has to do with being trustworthy. Can your enemy trust you in the market place? Can he trust you just the same as your friend can trust you? And as much as you want to trust another person? Love your enemies. Can your enemies trust you in negotiations? Can your enemy trust you in the way you speak about him or her to your friends? Do you give correct information? Is your judgment well-balanced?

These are not questions for a future utopia of straw-eating lions, but for concrete social and political life. Do you abstain from prejudices toward your enemies and do you earnestly attempt to get to know them personally?

6. The connection in the Hebrew Bible is even stronger than in the chapter arrangement of modern Bibles. The Masoretic text keeps 6:4-7:11 together in one seder, not even interrupted by a petochah. It is thus read in one and the same lecture. By the strong break, even of a parash, after 7:11 the beginning of the present chapter 7 gets emphasis with its apex in 7:11 as a conclusion of the commandments about the extinction of the people in Canaan.

7. See about this topic extensively Van de Beek, 2002, esp. pp. 321-397. 
"Love your enemies" is not about fine feelings for them, but about doing right by them and speaking truthfully about them. That implies sincere enquiry, and fathoming what is really at stake. For that reason, loving your enemies is much more difficult than loving your friends. This is not because your feelings for your friends are positive and those for your enemies negative. It is because it is so hard to understand your enemy. You can speak to your friends, listen to their answers and ask again and again, from heart to heart. You can understand your friends. But how do you understand your enemies? States send spies to enemies in order to understand them. That is not love, for the understanding is not used for faithfulness toward the enemies, but in order to overcome them. Love tries to understand the enemy, in order to deal with him openly.

"You have heard that it was said: 'Love your neighbour - the people of your own community - and hate your enemy.' But I tell you: Love your enemies" (Mt. 5:43f). Most people interpret this last phrase independently: "Love your enemies." Then it means: "We must try to do so as much as possible, but we know it is difficult." However, we should keep the couple together: love and hate. In biblical language that is a fixed couple, which is not about absolute love and hate, but about preference. For instance, a man who has two wives is not allowed to give more to the one he likes most, and to her children. He must give equally to both, and to their children as well (Dt. 21:15f). He does not hate the less preferred wife, but just likes the other one more. Or in the example of Jesus: "No one can serve two masters. He will hate the one and love the other"(Mt. 6:24). Love in this coupling thus implies preference. ${ }^{8}$ Now we come again to the saying: "It was said: 'Love your neighbour and hate your enemy."' You must prefer your kinsmen before your enemies. "Of course," we would say. However, Jesus says: "No, prefer your enemies. Invest more in them. Try to understand them and deal correctly with them. In your life, you should give this preference." That is even more important than giving offerings in the temple (Mt. 5:24).

If we consider how difficult it is to understand friends, brothers and sisters, fathers and mothers, children and partners, then we must conclude that this command is an enormous challenge, much more than an utopian ideal of emotional love for the enemies can ever be. ${ }^{9}$ We must notice that even in the New Testament letters, this claim is already softened: "Let us do good to all people, especially to those who belong to the family of believers" (Gal. 6:10). The family deserves preference. So we are back to: "Love your neighbour and hate your enemy." However, the latter verse is an exception. The normal implication of love is that you consider others higher than yourself (Php. 2:3). The other one has priority, even if that other one is your enemy.

It is this practical Christian love that conquered the Roman Empire. The characteristic of Christians was not that they were good friends in the same social sphere. In that case they would not have differed from the Hellenistic stoic elite. But they gave priority to those who were not of their own kind: the poor, the strangers, the orphans, the lepers. They built an organization for the care of widows. They did not kill, not even an enemy in war. Without boasting, the church fathers of the second century could claim that Christian life made a real difference in the Hellenistic world. And people knew this, and so the Christian community grew. ${ }^{10}$ When the emperor Julian, after the Constantinian turn, wanted to go back to paganism,

\footnotetext{
8. One should also take the continuation of Jesus' argument into account: a master can claim everything from his slave and it is impossible to have two absolute claims.

9. Also in Hos. 6:6 love and knowledge are considered as parallels.

10. Justinus, Apologia I,14; Athenagoras, Legatio pro Christianis 11; 32-35; Ad Diognetum 5v;

Origenes, Contra Celsum III,29.
} 
NGTT: Oopbron - http://ngtt.journals.ac.za

he was convinced that this could only be successful if they would also organize care for orphans and widows (Bowersock, 1978:87v; Aalders, 1983:111-113). Practical Christian agapè had overcome stoic philia.

\section{A gOVERNMENT OF AGAPÈ}

It would be a blessing if this kind of social life was not restricted to the Christian community, but shaped the face of society as a whole. This is what I call "agapocracy": that the rule of societal life be agapè: practical love, with people who can be trusted and are faithful. We can say that Christianity made a real impact on societal structures and behaviour, and it is not necessary to repeat this statement. Even in spite of many bad things both in the church and in Christendom, there is indeed a spin-off from Christian ethics that influenced societies where Christians were substantially active, and even the world society as a whole.

From the perspective of a Christian theology of ethics we must, however, ask: is our society based on agapè? Is this its leading principle? That is what makes the difference. This can be applied both to the interrelations of citizens and to the government. It is not important how the government is elected and which political system we have. I think Calvin's reflections on this point are still true (Institutes IV,20,8): an absolute monarchy will usually not be the best system, for little human beings must always be corrected by other people. A plural government will be better. However, a people's democracy can also be a risk, for politics is complicated, and people can easily be deceived by opportunistic leaders. The notorious example is Hitler who was democratically chosen by the majority of the German people - and I note similar populist results of elections in European countries nowadays, though fortunately not with a similar impact. It is not the question who decides, but what is decided. Christians should focus on that. The church should not judge a government on its democratic character, but on its "agapocratic" character. For the question is not whether it listens to the majority of the people (which can be very oppressive, aggressive and egoistic) but whether it is doing good to all people. Leaders cannot justify themselves by being chosen by the people, but only if they rule for the people.

Christians can and must judge the government, and society at large, according to the rule of love - the practical love of agapè. And if you focus on politics and societal organization, should you not be actively involved in it? Should Christians not be involved in societal and political changes so that love can be the rule of life? This question has been positively answered since the time of Constantine. Indeed, the role of Christians in South Africa in the transition of 1994 is exemplary - just as the role of Christians was exemplary in the denial of the rule of love, whereby all the characteristics of love, that 1 Corinthians 13 sums up, were reversed.

Nevertheless, there remains an uneasiness for which I do not have an answer. As often happens in critical scholarly work, we end up with more questions than answers. This uneasiness was already manifest in early Christianity, represented both in the New Testament and anteConstantinian church fathers. The most explicit examples are to be found in Tertullian and Origen, but it is generally present in writings from the first to the third century. Tertullian says: "We have no pressing inducement to take part in your public meetings; nor is there anything more entirely foreign to us than affairs of state."11 Origen shares his opinion. ${ }^{12}$ Christians should

11. Apologia 38.

12. Origenes, Contra Celsum VIII,75. 
not participate in government and political affairs. Why not? It is because politics have to do with power - ultimately with the power to kill. As the government is authorized to issue each police officer with a firearm, so, too, it is authorized to have tanks and strike fighters. At the very moment you participate in this system, you become responsible for the death of people - for as Paul says: the government does not bear the sword for nothing (Rm. 13:4). Tertullian and Origen were very resolute: keep your hands off this system. You can and must pray for the government, but you should not participate in its practice. ${ }^{13}$ Paul also writes in this vein (1 Tim. 2:2; Eph. 5:11), and so it is written in the Roman church law at the beginning of the third century: no soldier can become a Christian unless he gives up his job. ${ }^{14}$ On the other hand, however, what if someone attacks me to highjack my car and threatens my life? What if I see a man torturing a child and I have a stout stick in my hand? What if terrorist groups kill people in a market place? Is it not the rule of love to defend the victims? Should we not do something against individual criminals and oppressing regimes? Should we not participate in the government precisely in order to prevent it from becoming oppressive? And should we not give our energy to build such a society that people are not so desperate that they hijack cars or torture children? Certainly, we will not create a perfect society, but should we, being in this world, not do the next best thing? That is what Christian ethics, since the days of Bonhoeffer and Barth, since Beyers Naudé and Desmond Tutu, have proclaimed.

There are presently two mainstreams in Christian ethics. One supports a consolidation of dominant power. People should be obedient to the government and the government guarantees traditional Christian values. In the South African perspective, it may seem that this was the option in the past. However, in the USA for instance, it is alive and kicking, with the American flag in almost every church. Indeed, even theology in South Africa is continuously at risk to turn back to the old tradition of providing the present political system with a theological underpinning.

The other stream is critical of this. That does not necessarily mean revolutionary action, but rather a continuous reminding of the government of its proper responsibility to the people. It is the prophetic approach as it has been developed since the time of Barmen and was taken over by leading South African theologians since the sixties of the twentieth century.

If I must choose between these two options my choice is for the latter. It gives voice to the oppressed. It reveals evil systems and structures. It is critical just as early Christianity was critical of the powers of the beast, not only in the book of Revelation, but also by the very theologians I mentioned: Tertullian, Origen, and before them Ignatius and Justin. I find it a shame that Eusebius, in the beginning of the fourth century, changed his history of martyrdom into a prologue of the imperial power of Constantine. ${ }^{15}$

So here is no debate for me on this. Yet the uneasiness wells up from the more radical aspects of early Christianity - and radical voices of today as well. ${ }^{16}$ We can opt for a prophetic voice and for a contribution of Christians to a society of love. My worry, however, is that love is too easily replaced by rights. It really makes a difference if we see the other one as a person for whom we

13. Origenes, Contra Celsum VIII,73f.

14. Traditio Apostolica 16 (Sources Chrétiennes 11bis: 72).

15. Eusebius was writing a work on the history on Christian martyrdom when the Constantinian turn happened. He then changed the perspective of the same material: the history of the martyrs became merely the prologue of the glorious empire of Constantine.

16. See esp. the work of Hauerwas (Hauerwas, 1995; 2000; Hauerwas \& Willimon, 1989; 1996) 
NGTT: Oopbron - http://ngtt.journals.ac.za

must be trustworthy or from whom we claim our right. In the first case the other one is in focus, in the latter we are in the centre. ${ }^{17}$ In that case we are back in ancient Rome - and Roman law is still dominant in today's judicial systems of individual rights and possession of property. ${ }^{18}$ Even the will to defend a threatened people leads all too easily to a so-called just war, for who defines what is 'just' other than the one who begins the war? Should we not be more radical, something of which Stanley Hauerwas never tires? He tells the story of the American soldier who refused the execution of a Vietnamese, though the latter was a murderer, but who was just a boy (Hauerwas, 1995:2). At the very moment you see an individual not as one of a class, but as a human being, he or she calls for agapè - even to such an extent, says Jesus, that he or she enjoys priority with me. Tertullian tells the story of a young Christian who, while being a soldier, was converted and no longer accepted anything from the army, not even the crown of victory of his company. "I am a Christian" is his only argument. "For," says Tertullian, "is the laurel of the triumph made of leaves, or of corpses? Is it adorned with ribbons, or with tombs? Is it bedewed with ointments, or with the tears of wives and mothers?" And he continues: "also among the barbarians is Christ." 19

The only political system that is right, according to the Christian faith, is agapocracy. But can you exact agapocracy by force - as governments are prone to do? For ultimately, force is the power of the bullet! Should the church be involved in political change for a better society? The 1989-1994 transitions were relatively peaceful, but what about Bosnia, Libya, Syria? What would happen if the Russian and the Chinese people claim democratic freedom? Should we not choose the other track? Should the church not go its own way as an alternative community, as Hauerwas says, precisely because we are responsible for human beings, also for Vietnamese human beings? Everywhere in the church I see people who make their decisions based on fear and power. Both are closely related. The powerless claim power and call for empowerment. The powerful are continuously in fear of losing power and possessions.

However, love is not a good feeling: it is agapè: very concrete faithfulness. Should not the church at least be a place of agapocracy? An agapocratic alternative community - with at its centre the meal where we remember the death of Him who loved the world? Agapocracy comes at the expense of power, of self-saving, of rights, of possessions. It is sacrifice, if need be even unto death, because the other one has priority. The church father Ignatius is grateful that he is allowed to bring this sacrifice. "Do not plea for me to get me free."20 For the sacrifice of love is ultimately the sacrifice for God who is love - or even more: it is the sacrifice whereby Christ through the members of his body sacrifices Himself for the world.

That is my dilemma: the prophets or the martyrs? Isaiah or Ignatius? Amos or Tertullian? My natural tendency is to opt for the prophets. But I feel this has to do with fear of losing what I have or the desire to gain what I want. Between the prophets and the martyrs is Jesus and Him

17. Dr. H. Bosman (Stellenbosch) directed my attention to the Song of Songs where it is also the other one who is important in love: it is not my grasping of the other's body but the glory of his and her beauty that evokes the songs. He gave also other hints for this article that I gratefully accepted.

18. The implications of individualism in Roman law were painfully displayed in a court case in the Netherlands, where the legal system is based on Roman law. Two boys tried to hold up a hotel but they were taken by surprise by the police. They fled on a scooter and ran over a man who died. Nevertheless, in court they were successfully pleaded free because it was not certain which of the two was driving the scooter, and therefore guilty. .

19. De corona 12.

20. Ignatius, Ad Romanos 2-5. 
NGTT Deel 54, Nommers 1 \& 2, Maart en Junie 2013

crucified. And that act of love, concrete agapè, turns my life upside down. Once again: what to do when I see a man torturing a child and I have a stout stick in my hand? What to say about the office of untrustworthy ministers? I have no response to Jesus' reaction to untrustworthy Peter: "Feed my lambs" (Jn 21:15). Is any agapè to people like him not a betrayal of the little ones? Christian love - who knows how to deal with it?

Consequently, any Christian is in the position of Paul who writes: "If I want to do good, evil is right there with me" (Rom. 7:21). If we liberate this verse from its egocentric psychological interpretation and see it as the condition of Christians in the world, we notice the dilemma wherein Christians are. I cannot finish this essay with solid solutions for the problem I encountered. Rather, I problematized situations where fixed ideas seemingly provided a solid ground. However, this course of reasoning is more productive for scholarly work than the other way around - and more fruitful for living as well.

\section{BiBLIOGRAPHY}

Aalders, G.D.J. 1983. Julianus de Afvallige. Het leven van een verbitterde keizer. Kampen: Kok.

Benedictus XVI, Deus est caritas. http://www.vatican.va/holy father/benedict xvi/encyclicals/documents/ hf ben-xvi enc 20051225 deus-caritas-est en.html (consulted 31 May 2012).

Bowersock, G.W. 1978. Julian the Apostate. Cambridge (Mass.): Harvard University Press.

Hauerwas, S. 1995. In God's Company: the Church as Polis. Notre Dame/London: University of Notre Dame Press.

2000. A Better Hope: Resources for a Church Confronting Capitalism, Democracy, and Postmodernity. Grand Rapids: Brazos Press.

Hauerwas, S. \& W.H. Willimon. 1989. Resident Aliens: a Provocative Christian Assessment of Culture and Ministry for People who Know that Something is Wrong. Nashville: Abingdon Press.

1996. Where Resident Aliens Live: Exercises for Christian Practice. Nashville: Abingdon Press.

Nygren, A. 1930; 1936. Den kristna kärlekstanken genom tiderna: Eros och Agape. Stockholm: Svenska kyrkans diakonistyrelses bokförlag.

1953. Agape and Eros. Philadelphia: Fortress Press.

Ray, S.K. 2002. St. John's Gospel. A Bible Study Guide and Commentary. San Francisco: Ignatius Press.

Stauffer, E.1964. "Agapao etc" in: Theological Dictionary of the New Testament I. Grand Rapids: Eerdmans: 21-55.

Theron, P.F. 2010. Gods geregtigheid en Christus se geloof. Oor die tekens van God se trou. Wellington: BybelMedia.

Van de Beek, A. 2002. De kring om de Messias: Israël als volk van de lijdende Heer. Spreken over God 1,2. Zoetermeer: Meinema.

2006. Onward Christian Soldiers! Christians in the Army. Acta Theologica, 26(1):165-185.

Wallis, G. 1973. 'ahab. (In: G.J. Botterweck \& H. Ringgren (Hsgb.), Theologisches Wörterbuch zum Alten Testament I, Stuttgart/Berlin/Köln/Mainz, Verlag W. Kohlhammer. p. 105-128.)

\section{KEY WORDS}

Agape

love

agapocracy

Church

Christian ethics

\section{TREFWOORDE}

Agape

liefde

agapokrasie 
NGTT: Oopbron - http://ngtt.journals.ac.za

kerk

Christelike etiek

\section{Contact Details}

Prof. Abraham van de Beek

Petenbos 8,

3904 BN Veenendaal,

The Netherlands

E-pos: beekavd@xs4all.nl 